\title{
COMPARATIVE ASSESSMENT AND COST- ESTIMATION OF GFRP RC AND STEEL RC COMPOSITE (BOX MULTI-CELL TYPE) BRIDGE USING STAADPRO
}

\author{
Ms. Veena Maroti Suryawanshi \\ M.Tech Student \\ Department of Civil Engineering \\ Shri Guru Gobind Singhji Institute of Engineering \\ and Technology, Nanded
}

Abstract- While examining regarding the establishment within India, and all the most explicitly, the issues confronting India's structure, failure of bridges has been one of the principal issues facing India's system. Failure of bridges regularly are exorbitant in the trade predestined, lives lost, and substitution reserves needed to remake the bombed connect. In minding the past interface disillusionments, it is normal, or synthetic that with most noteworthy death toll and straightforwardly influences the people just as nation economy. From this past dissatisfaction it is important to concentrate how to reinforce the future development.

Conventional materials have neglected to satisfy the requirements for extreme, secured and low-support roads and bridges. Steel bar can undoubtedly be vulnerability to erosion (corrosion) or oxidation when introduced to salts, intense engineered substances, and moistness that prompts further and speedier debilitating of the steel and concrete. The degree of the assessment is taking "disintegration" as a reason for dissatisfaction into thought so the design ought to be strengthened by using advanced composite material i.e., Glass Fiber Reinforced Polymer (GFRP) and differentiating with Steel. GFRP composites offer high solidarity to-weight proportion, phenomenal weakness opposition, and extra security against thruway climate conditions and decrease the general life-cycle costs. . It is utilized to assemble cost-proficient construction with a life expectancy of more than 100 years.

The main purpose of research is relative assessment, plan and cost-appraisal of the composite (box multi-cell type) bridge having Reversed L-Shaped Cantilever Retaining wall with GFRP-Reinforced Concrete and Steel Reinforced Concrete material. Finally, the bridge is analyzed using Finite Element Method demonstrating with STAAD PRO. The consequence of cost assessment shows that construction with GFRP material is much

\author{
Dr. G. D. Awchat \\ Professor \\ Department of Civil Engineering \\ Shri Gobind Singhji Institute of Engineering \\ and Technology, Nanded
}

conservative as contrast with structure with steel of 250mpa which is agreeable.

Keywords - Composite bridge, Box multi-cell type bridge, Finite Element Method (FEM), Glass Fiber Reinforcement Polymer (GFRP), STAAD Pro.

\section{INTRODUCTION}

The Road establishment in each state has been decaying at a quick speed for a long time. The constant decay is a consequence of weighty burdens, unforgiving ecological conditions, helpless upkeep rehearses, and the consumption of steel support. Conventional materials for bridges and roads have neglected to satisfy the developing public needs such as tough, protected and low-maintained. Lightweight, dependable primary parts and all around built offices are fundamental to accomplish monetary turn of events. Steel bar can undoubtedly be defenselessness to consumption or oxidation when presented to salts, forceful synthetics, and dampness. As it erodes, steel bar grows and expands the malleable burden on the substantial, which starts to break and spall, making openings that lead to further and quicker decay of the steel and cement. This causes expensive fix and support and furthermore need restoration in just 5 to 10 years and every now and again need significant recovery inside 20 years.

It is important to shield the concrete from harm by freezing and defrosting cycles. Air likewise decreases exudation and is expanded penetrability because of exudation water channels. Stripping the concrete surface can speed up the erosion harm of inserted support bars. An incredible answer for totally eliminate the opportunity of erosion in building structures is the utilization of Glass Fiber Built up Polymer (G.F.R.P.), also called fiberglass rebar. 


\subsection{Erosion Disintegration in RC Construction:}

It is the significant decay issue in R.C. Bridges. It decreases the existence of the designs. It results in the strength and functionality misfortune in the R.C. components. Progressed composite materials like Glass Fiber Reinforced Polymer (G.F.R.P.) bar have been created to address the deficiencies of conventional materials. Erosion, extensive development interaction, and substantial support are the significant downsides of steel and other obsolete development materials. While these inventive development arrangements can decrease the general life-cycle costs, it's presently conceivable to speed up the maintenance and development measures with composites.

\subsection{Fiber Reinforced Polymer (FRP):}

Concrete being generally exceptionally solid in pressure yet poor in strain; it has little protection from breaking and keeps an eye on weak. The shortcoming in strain can be surpassed by Performance Improvement of Concrete Structures utilizing Natural Fiber Composites.

The common FRP composite fortifications used in structural designing are constructed through a pultrusions procedure from,

1. Glass Fiber Reinforced Polymer (GFRP)

2. Carbon Fiber Reinforced Polymer (CFRP)

3. Basalt Fiber Reinforced Polymer (BFRP)

4. Aramid Fiber Reinforced Polymer (AFRP)

For this present study GFRP Composite material is being used.

\section{Glass Fiber Reinforced Polymer (GFRP):}

Glass fibers, which are otherwise called fiberglass \& generally mixed at $0.5 \%-2.0 \%$ by weight to the composite are alluded to as fiber glass fortified polymer. G.F.R.P. is a kind of plastic compound that correctly utilizes glass fiber ingredients to instinctually build the firmness \& capacity of plastics. GFRP bar can likewise drop costs by eliminating the utilization of work, decline establishment charges, diminish the requirement for upkeep, and has a more extended life expectancy than numerous awards. Here are a portion of the benefits of utilizing G.F.R.P. rebar in different applications:

- The constituents of G.F.R.P. incorporate excellent erosion safe vinyl ester tar that expands the life expectancy of a substantial design.
* As contrasted and the customary support material, G.F.R.P. rebar is $1 / 4$ the heaviness of steel with $2 x$ the rigidity of steel.

* G.F.R.P. rebar is non-conductive to power and warmth settling on it an optimal decision for offices like force age plants and logical establishments. .

* It is resistant to chloride particles and other compound components.

\subsection{Reversed L-Shaped Cantilever type Retaining Wall: \\ It opposes the even earth pressure just as other} vertical pressing factor via twisting of different segments going about as cantilever.

May be L shaped or T shaped.

\subsection{Live load (IRC6):}

The live load on the bridge is moving load on the extension all via its length. The vehicle loadings are classified in to three kinds and they are

1. I.R.C. class AA loading

2. I.R.C .class A loading

3. I.R.C. class B loading

In this present study I.R.C. class AA loading is considered.

\section{I.R.C. class AA loading:}

This kind of loading is assumed for the design of new bridge especially high loading bridges such as bridges on highways in cities, industrial areas etc. In class AA loading normally two kinds of vehicles assumed \& they are,

a. Tracked type

b. Wheeled type

\section{OBJECTIVES:}

1. To Study and select the type of "Fiber Reinforced Polymer" Composite Material.

2. To study and select the type of Retaining wall.

3. Analysis of Multi-Cell box Type Bridge with steelconcrete \& FRP-concrete composite material with retaining wall.

4. Design of Multi-Cell box Type Bridge with steelconcrete \& FRP-concrete composite material with retaining wall.

5. Study of cost estimation of Multi cell box type Bridge with steel-concrete \& FRP-concrete composite material. 
6. Comparative study of Multi cell box Type Bridge with steel-concrete \& FRP-concrete composite material.

\section{PROBLEM STATEMENT}

Design a Composite box 7cell Bridge having inside dimensions of each box is $3.5 \mathrm{~m} \times 3.5 \mathrm{~m}$. This bridge is subjected to a live load of IRC Class AA tracked vehicle. Assume the unit weight of soil to be $18000 \mathrm{~N} / \mathrm{m}^{3}$. The angle of repose of soil is $30^{\circ}$. The unit weight of asphalt wearing material to be $23600 \mathrm{~N} / \mathrm{m}^{3}$. Thickness of wearing surface is to be $80 \mathrm{~mm}$. Use M30 concrete and Fe250 steel. Road width is $7.5 \mathrm{~m}$. Assume Fiber reinforced strength 1000 MPA.

\subsection{Assumption of Geometry:}

- Design methodology: 3D Modeling

- Number of cells: 7

- Top Slab thickness: 300mm

- Bottom slab thickness: $300 \mathrm{~mm}$

- $\quad$ Side (external) wall thickness: $300 \mathrm{~mm}$

- $\quad$ Side (Internal) wall thickness: $250 \mathrm{~mm}$

- Clear inside dimension (rise): $3500 \mathrm{~mm}$

- Clear inside dimension (span): $3500 \mathrm{~mm}$

- Head wall width: $350 \mathrm{~mm}$

\subsection{Description of Load Consideration:}

2.2.1 Dead Load: - Self-weight of the structure: Applied automatic by the program STAAD PRO V8i.

2.2.2 Superimposed Dead Load :- Asphalt Wearing Course weight : $1.88 \mathrm{KN} / \mathrm{m} 2$ (applied on top of slab)

2.2.3 Lateral earth pressure:- The Rankine active \& passive earth pressure co-efficient for the specific situation of a lateral backfill surface is evaluated as below,

$$
\begin{aligned}
& \text { (Active) } \mathrm{Ka}=(1-\sin (\varphi)) /(1+\sin (\varphi)) \\
& \text { (Passive) Kp }=(1+\sin (\varphi)) /(1-\sin (\varphi))
\end{aligned}
$$

Thus, the total $\mathrm{c}$ force $(\mathrm{Pa})$ acting along the back of the wall $\&$ is the area of the pressure diagram expressed as,

$$
\mathrm{Pa}=1 / 2 \mathrm{Ka} \gamma \mathrm{H} 2
$$

The total passive earth pressure force is:

$$
\mathrm{Pp}=1 / 2 \mathrm{Kp} \gamma \mathrm{H} 2
$$

Where,

$\mathrm{Ka}=$ Coefficient of Active Earth Pressure

$\mathrm{Kp}=$ Coefficient of Passive Earth Pressure

$\Phi=$ Angle of Repose

$\mathrm{Pa}=$ Total Active Earth Pressure

$\mathrm{Pp}=$ Total Passive Earth Pressure

$\gamma=$ Density of soil

$\mathrm{H}=$ Total height of structure

- Horizontal Earth Pressure (IRC 6)

- Co-efficient of active earth pressure (ka): 0.3333

- Co- efficient Of Earth pressure at rest $\left(\mathrm{K}_{0}\right): 0.5$

- Height at center line on top slab: $280 \mathrm{~mm}$

- Height at center line on bottom slab: $4180 \mathrm{~mm}$

- Active earth pressure (min. HEP)

- At Top - $1.68 \mathrm{KN} / \mathrm{m}^{2}$

- At bottom- $25.08 \mathrm{KN} / \mathrm{m}^{2}$

- Active earth pressure (max. HEP)

- At Top - $2.52 \mathrm{KN} / \mathrm{m}^{2}$

- At bottom- $37.62 \mathrm{KN} / \mathrm{m}^{2}$

\subsection{Structural Data Assumed:}

Considering lower strength of steel that is 250 MPA and strength of F.R.P. as 1000 MPA reason is that in STAAD PRO Software there is a limit of strength value up to 1000MPA only that why need to select the last value 1000MPA for FRP.

It is required to use tensile strength of $250 \mathrm{Mpa}$ for Steel and 1000Mpa for F.R.P.; if you use a higher value of Tensile steel the same value will obtain as that of FRP.

\section{MODELING}

The Structural plan imported in STAAD Pro must be in .dxf format which is drawn in AutoCAD. Following is stepwise procedure.

\subsection{STEPS:}

Step 1: Place the nodes at each corner by selecting node cursor and join the nodes with the help of beam cursor as a beam with the help of translational repeat command and apply meshing in each span. 


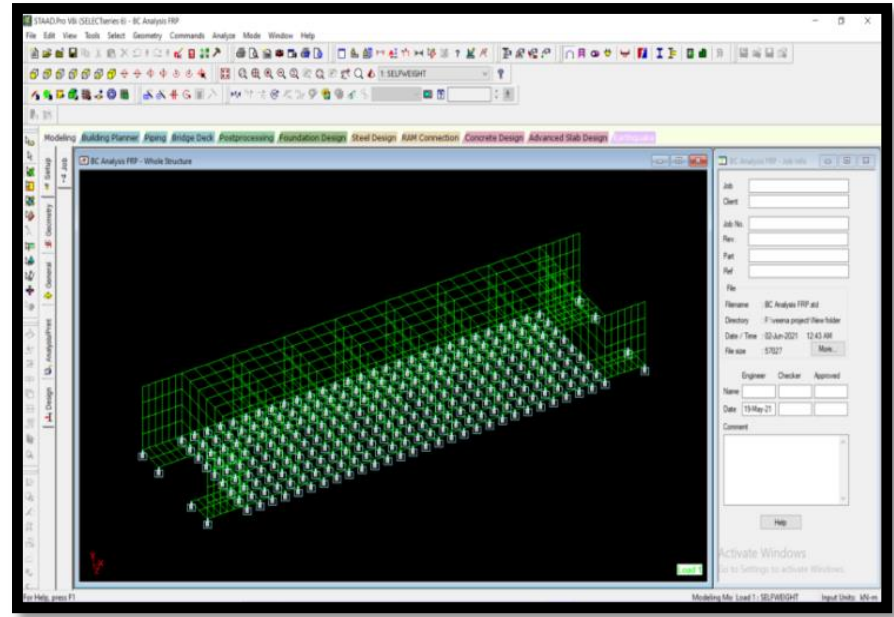

Step 2: After completion of geometry of model go to the general tab and define the property of each member.

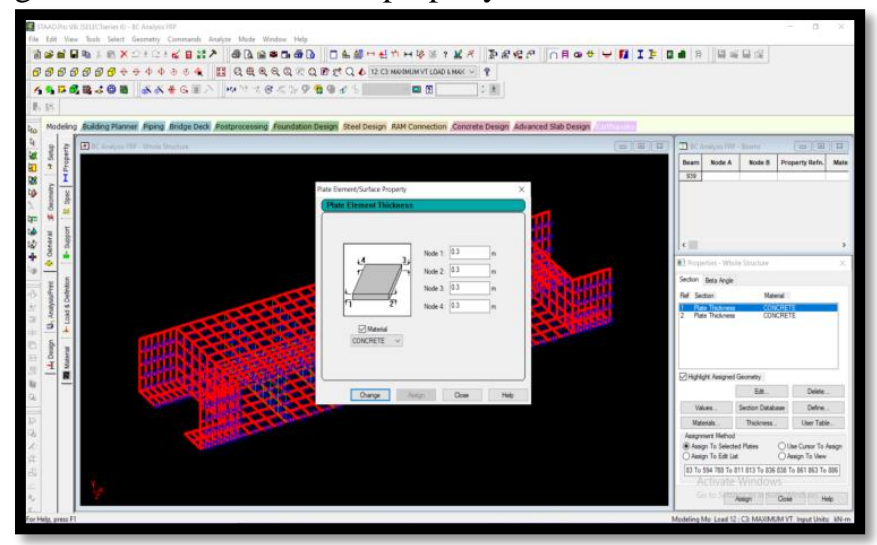

Step 3: Load Envelope Applied on the Box Culvert.

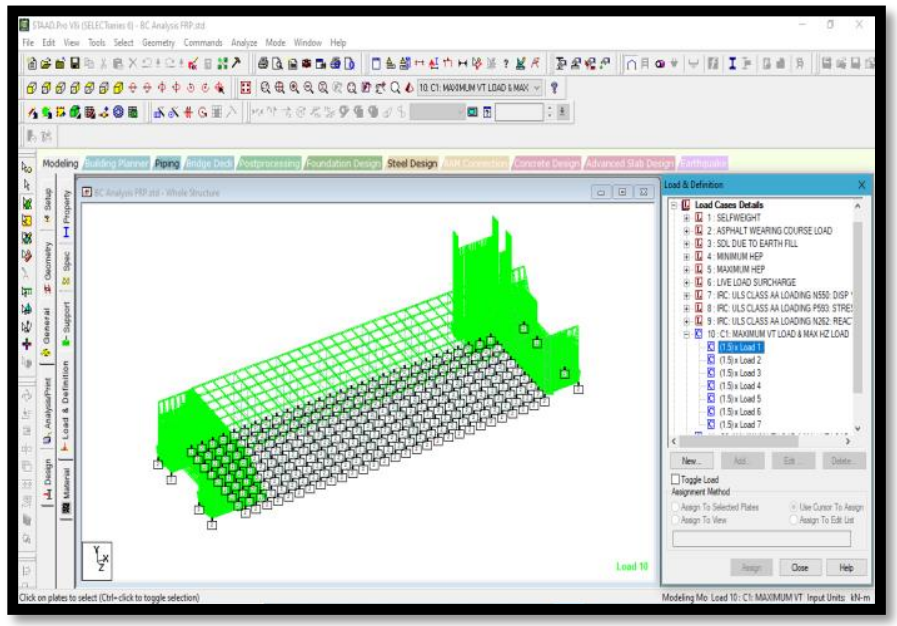

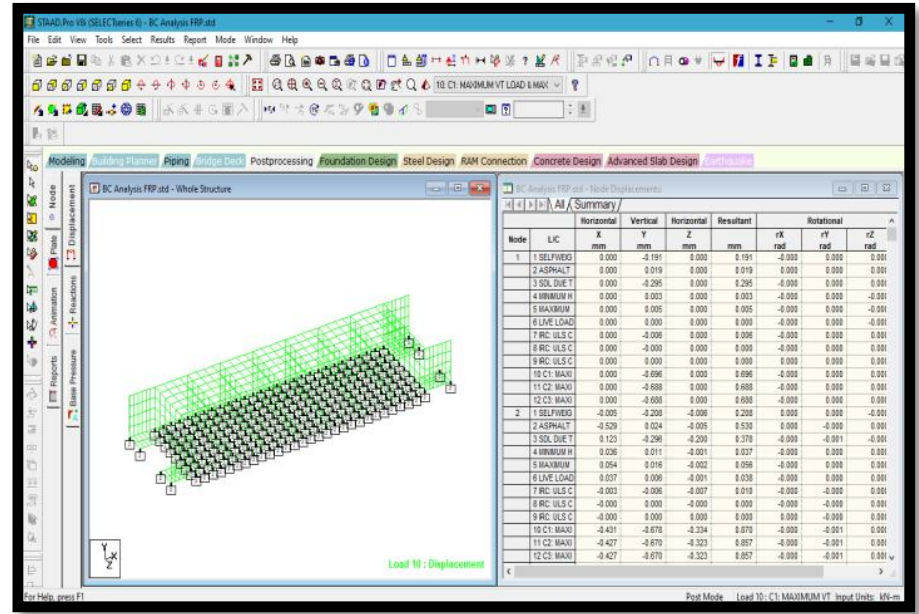

Step 4: Box culvert analysis process we got some results such as deflection, support reactions, base pressure for the different loading conditions. Below fig shows analysis results.

Step 5: For the design process in need to apply preferable IS code that is 456-2000 for the RC design. Some parameter will be defined for the design process such as clear cover, compressive strength of concrete and yield strength of the steel reinforcement and FRP reinforcement.

\section{RESULTS AND DISCUSSION}

\subsection{Estimation of concrete work:}

Concrete work in an undertaking ordinarily holds the greatest weight age as far as generally overall expense and work quantity. It's anything but a significant advance to compute the concrete related expenses while setting up a project estimate. The expense of concrete relies on the expense of materials, blend design, labor force, and machinery.

\subsection{Additional Cost of Concreting:}

The above cost given is just for the raw materials of concrete. The complete cost of concrete includes the cost of mixing, transporting, compaction equipment, reinforcement, and formwork and labor charges. We consider DSR 19-20's rate for estimation purpose which consist of all these additional costs. Cost of concrete is calculated by multiplying the volume of structure (cross section) to the rate of concrete from DSR as follows:-

- Total volume of concrete work is $2682.25 \mathrm{~m}^{3}$

- Total cost of concrete work is 20127604.0 Rs.

\subsubsection{Mild Steel (FE250):}


Total number of Bars required in Lateral direction for Steel (250MPA) is 5406.432 RMT \& in Longitudinal directions is 4529.28 RMT including top slab, bottom slab (including retaining wall bottom wall), side wall(external), shear key(retaining wall), vertical wall(all internal wall and retaining wall).

\begin{tabular}{|c|c|c|c|}
\hline \multicolumn{3}{|c|}{ Total Running Meter of Bar } & 9935.71 \\
\hline $\begin{array}{l}\text { Per meter } \\
\text { weight }(\mathrm{kg})\end{array}$ & Total meter & \multicolumn{2}{|c|}{ Total wt. in $\mathrm{kg}$} \\
\hline 0.889 & 9935.71 & 8832.85 & $\mathrm{~kg}$ \\
\hline \multicolumn{2}{|c|}{ Total weight in $\mathrm{kg}$} & Rate/Kg & Amount \\
\hline 8832.85 & $\mathrm{Kg}$ & 60 & $5,29,970.88$ \\
\hline
\end{tabular}

Total Amount of Reinforcement required for steel reinforced concrete bridge is Rs. 5, 29,970.88

\section{* Overall Cost of steel RC bridge:}

Total cost concrete (excluding Steel reinforcement):

$$
\text { Volume of concrete }=2682.25 \mathrm{~m}^{\wedge} 3
$$

Volume $=$ Weight $/$ Density

Steel Density $=7850 \mathrm{Kg} / \mathrm{m}^{\wedge} 3$

Volume of steel $(250)=8831.744 / 7850=1.125 \mathrm{~m}^{\wedge} 3$

Total volume of concrete (excluding Reinforcement)

$=$ Volume of concrete - Volume of steel (250)

$$
\begin{aligned}
& =2682.25 \mathrm{~m}^{\wedge} 3-1.125 \mathrm{~m}^{\wedge} 3 \\
& =2681,13 \mathrm{~m}^{\wedge} 3
\end{aligned}
$$

Overall cost of concrete,

$$
\begin{aligned}
& =\text { Volume of concrete Rate (as per DSR) } \\
& =2681.13 \times 7504 \\
& =\text { Rs. } 2,01,19,199.52 /-
\end{aligned}
$$

Overall cost of steel (250) RC bridge,

$$
=\text { Cost of concrete }+ \text { Cost of steel (250) }
$$$$
=\text { Rs 2, 01, 19,199.52+5, 29,970.88 }
$$

$=\operatorname{Rs} 2,06,49,170.4 /-$
Overall cost required for steel (250) RC bridge including steel and concrete charges is Rs 2, 06, 49,170.4/-

\subsubsection{GFRP (FE1000):}

\begin{tabular}{|c|c|c|c|}
\hline \multicolumn{3}{|c|}{ Total Running Meter of Bar } & 9155.2 \\
\hline $\begin{array}{l}\text { Per meter } \\
\text { weight }(\mathrm{kg})\end{array}$ & Total meter & \multicolumn{2}{|c|}{ Total wt. in $\mathrm{kg}$} \\
\hline 0.889 & 9155.23 & 8139.0 & $\mathrm{~kg}$ \\
\hline \multicolumn{2}{|c|}{ Total weight in $\mathrm{kg}$} & Rate/Kg & Amount \\
\hline 8139.0 & $\mathrm{Kg}$ & 55 & 4,47,654.07 \\
\hline
\end{tabular}

Total number of Bars required in Lateral direction for G.F.R.P.(1000MPA) is 4998.432 RMT \& in Longitudinal directions is 4156.80 RMT including top slab, bottom slab (including retaining wall bottom wall), side wall(external), shear key(retaining wall), vertical wall(all internal wall and retaining wall).

Total Amount of Reinforcement required for G.F.R.P. Reinforced Concrete Bridge is Rs. 4, 47,645.07

\section{- Overall Cost of GFRP RC bridge:}

Total cost concrete (excluding G.F.R.P. reinforcement):

$$
\begin{aligned}
& \text { Volume of concrete }=2682.25 \mathrm{~m}^{\wedge} 3 \\
& \text { Volume }=\text { Weight } / \text { Density } \\
& \text { Density of G.F.R.P. }=1850 \mathrm{Kg} / \mathrm{m}^{\wedge} 3
\end{aligned}
$$

Volume of G.F.R.P. $(1000)=8139.001248 / 1850=4.399$ $\mathrm{m}^{\wedge} 3$

Total volume of concrete (excluding Reinforcement):

=Volume of concrete - Volume of G.F.R.P.(1000)

$$
\begin{aligned}
& =2682.25 \mathrm{~m}^{\wedge} 3-4.399 \mathrm{~m}^{\wedge} 3 \\
& =2677.85 \mathrm{~m}^{\wedge} 3
\end{aligned}
$$

Overall cost of concrete,

$$
=\text { Volume of concrete } \mathrm{x} \text { Rate }
$$


$=2677.85 \times 7504$

= Rs. 20094590.45/-

Overall cost of G.F.R.P. (1000) RC bridge,

$=$ Cost of concrete + Cost of G.F.R.P. (1000)

= Rs. $20094590.45+447,645.07$

$=$ Rs. $2,05,42235.52 /-$

Overall cost required for G.F.R.P. RC bridge including steel and concrete charges is Rs. 2, 05, 42235.52/-

\subsection{Graphs:}

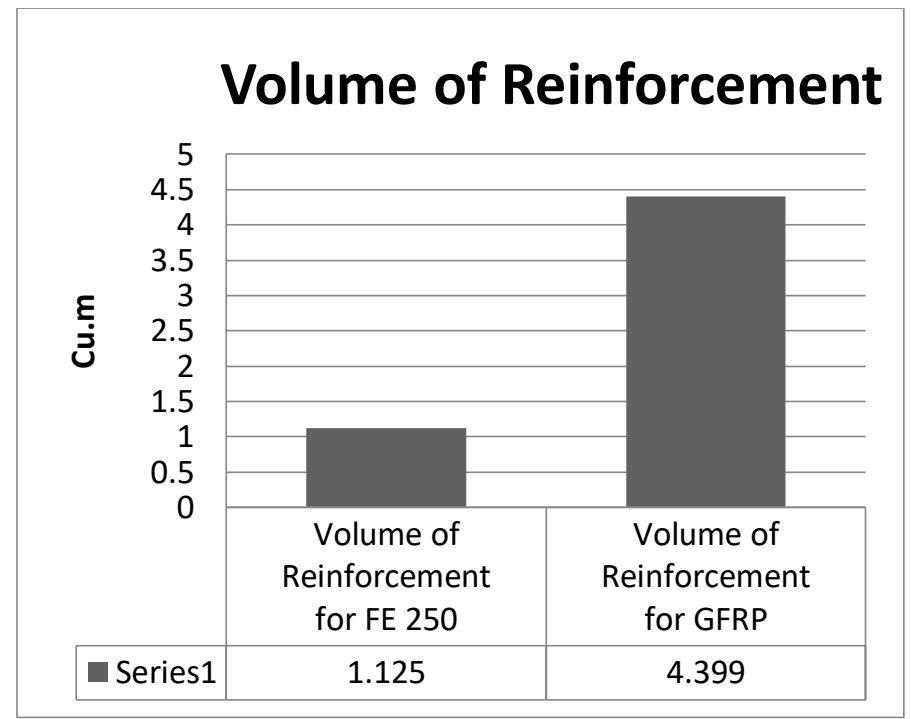

Graph show that the volume of Reinforcement required for Steel RC Bridge 1.125 Cu.m which is less than the volume required for G.F.R.P. RC Bridge is 4.399 cum.

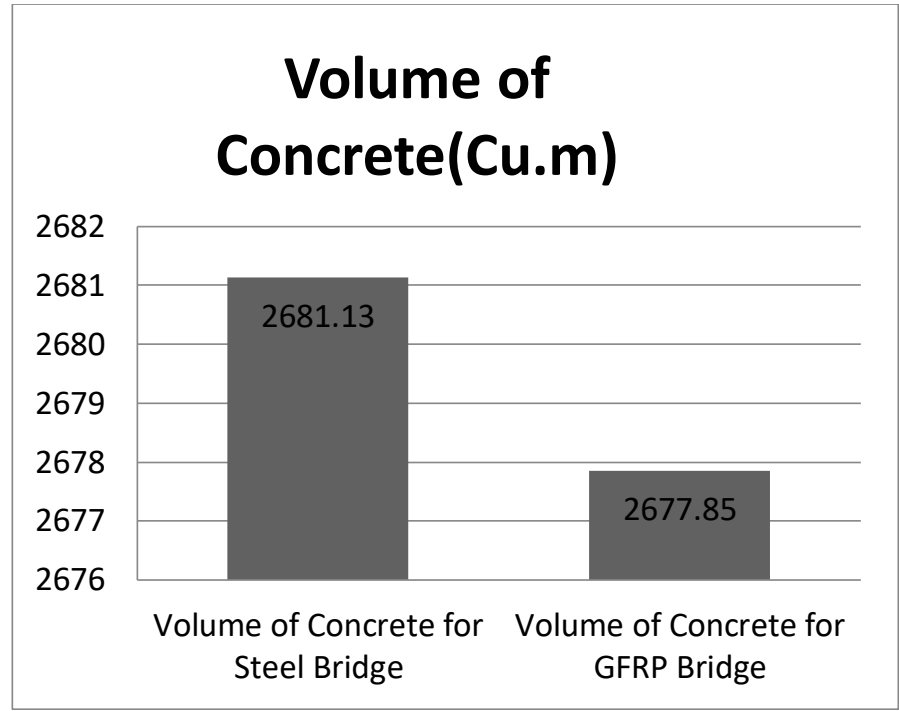

Graph shows that after deducting volume of particular reinforcement from the volume of concrete we get the actual volume of concrete required for Steel RC Bridge is $2681.13 \mathrm{Cu} . \mathrm{m}$ which is more than the volume of concrete required for G.F.R.P. RC Bridge i.e., 2677.85cu.m. From this actual volume of concrete, we directly calculate the actual cost of concrete required for particular bridge by multiplying it to the rate of concrete from DSR

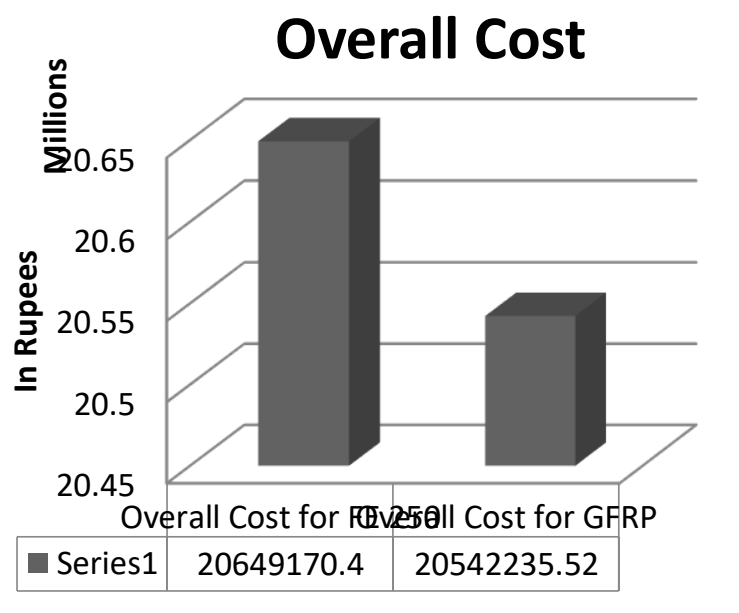

Graph shows that after adding the actual cost required for concrete to the cost of particular reinforcement gives the actual cost of steel RC bridge i.e.,Rs20649170.4/which is lot more than G.F.R.P. RC Bridge i.e.,Rs20542235.52/- ,we clearly see the difference of amount Rs106934.88/- required less for G.F.R.P. RC Bridge than the Steel RC Bridge. 


\section{CONCLUSION}

1. In this research thesis G.F.R.P. material is considered for making it composite design. This material contains glass as the supporting segment for the polymer network. It has high thickness and medium weight, additionally more affordable as contrast with other material.

2. After the investigation and plan, we found that measure of support needed for structure with G.F.R.P.(1000) concrete is significantly less were concerning the design with fe 250 required more space of steel.

a) It is needed to utilize rigidity of $250 \mathrm{Mpa}$ for Steel and 1000Mpa for G.F.R.P., on the off chance that you utilize a Higher worth of Tensile steel a similar worth will get as that of G.F.R.P.

b) Now the end is that the Amount of Steel gave is at least one, presently to acquire values with a critical sum perhaps we need to utilize the tallness of take care of in request to have huge burdens following up on the construction.

c) Using the Steel of 250Mpa and G.F.R.P. of 1000Mpa we note the changes. This implies that as the strength of reinforcement increases the amount of reinforcement used decreases (Inversely proportional).

3. Overall expense of Steel RC Bridge is more than the general expense of G.F.R.P. RC Bridge.

4. The result of cost examination shows that construction with G.F.R.P. material is much practical as contrast with structure with steel of $250 \mathrm{mpa}$ which is agreeable.

\section{REFERENCES}

[1] Abdalla, H., "Evaluation of deflection in concrete members reinforced with fibre reinforced polymer (FRP) bars Composite Structures", 2002.

[2] Dolan, C. W., Bakis, C. E., \& Nanni, A., "Design recommendations for concrete structures prestressed with FRP tendons", 2001.

[3] ACI Committee 440, "Guide for the Design and Construction of Structural Concrete Reinforced with FRP bars", Farmington Hills, Mich American Concrete Institute, 2006

[4] Katz, A., "Effect of Helical Wrapping on Fatigue Resistance of GFRP", Journal of Composites for Construction, 121 - 125, 1998.
[5] Ehsani, M. R., Saadatmanesh, H., \& Tao, S.., "Design Recommendations for Bond of GFRP Rebar's to Concrete", Journal of Structural Engineering, Vol. 122, No. 3, 247 - 254, 1996.

[6] Noel, M., \& Soudki, K., "Fatigue Behavior of GFR Reinforcing Bars in Air and in Concrete", Journal of Composites for Construction, 2014.

[7] Robert, M., Cousin, P., \& Benmokrane, B., "Durability of GFRP Reinforcing Bars Embedded in Moist Concrete", Journal of Composites for Construction, Vol. 13, No. 2, 66-73, 2009.

[8] Benmokrane, B., \& Wang, P., "Durability of FRP composites for civil infrastructures applications, a state of art report", Journal of Composites for Construction, 6(2), 143-153, 2002.

\section{Standard Codes:}

1. Indian Road Congress 6 (IRC 6)

2. IS456: 2000

3. DSR 2020-21 